\title{
Proposal to Increase the Level of Rural Business Activity after COVID-19
}

\author{
Mariia Tepliuk ${ }^{1}$, Mykhailo Sahaidak ${ }^{1}$, Svitlana Petrovska ${ }^{2}$, \\ Natalia Rudenko ${ }^{3}$, Mykhailo Matsola ${ }^{4}$ \\ ${ }^{1}$ Kyiv National Economic University named after V. Hetman, Kyiv, Ukraine \\ ${ }^{2}$ National Aviation University, Kyiv, Ukraine \\ ${ }^{3}$ Taras Shevchenko National University of Kyiv, Kyiv, Ukraine \\ ${ }^{4}$ Vasyl Stefanyk Precarpathian National University, Ivano-Frankivsk, Ukraine
}

\begin{abstract}
Our study uses a number of fundamental provisions of modern economics to ensure business excellence of enterprises, as well as used mathematical methods based on the use of integrated indicators in the direction of: leadership of scientific and technical cooperation, strategy of scientific and technical cooperation, people of knowledge, partnership and resources that matter, processes, products and services, research results, customer results, community and society vision. The study of key trends in the innovative development of domestic agribusiness is indicating the positive and negative aspects of proposal to increase the level of rural business activity. During the study it was found that this algorithm for assessing the level of business excellence, it is advisable to use it in order to identify the current state of the enterprise by the criteria of excellence, including evaluation of competitors. These exponential equations indicate that the algorithm of predictive calculation can be used in practice due to any changes in indicators.
\end{abstract}

Keywords - rural, agricultural, agribusiness, business activity, excellence model, integrated indicators, agricultural market.

DOI: $10.18421 /$ TEM102-21

https://doi.org/10.18421/TEM102-21

Corresponding author: Mariia Tepliuk, Kyiv National Economic University named after $V$. Hetman, Kyiv, Ukraine.

Email: maria 6.11@kneu.edu.ua

Received: 22 February 2021.

Revised: 01 May 2021.

Accepted: 06 May 2021.

Published: 27 May 2021.

(c) Br-NC-ND (C) 2021 Mariia Tepliuk et al; published by UIKTEN. This work is licensed under the Creative Commons Attribution-NonCommercial-NoDerivs 4.0 License.

The article is published with Open Access at www.temjournal.com

\section{Introduction}

As countries work to recover, grow and overcome the global economic and financial crisis associated with COVID-19, scholars and practitioners are focusing on renewing the development of rural enterprises as a key sector in supporting global survival. It is the stabilization of the rural market that will lead to economic growth, create jobs, and in the long run reduce poverty and hunger, which in turn will solve key social problems. Ensuring the efficiency of economic entities in modern conditions requires timely review of the needs of the external and internal environment and finding ways to meet them, which is possible through the use of innovations, competencies of the XXI century and a successful combination of resources. In modern conditions, the role and place of innovation are determined by the degree of scientific implementation and technical potential, in particular the achievement of macroeconomic stability, the revival of entrepreneurial activity with subsequent transformation processes [1], [16] characterized by fundamental changes in the structure of innovative economic system. It should be noted that in order to improve the business of rural enterprises it is necessary to intensify innovative development, maintain market positions and scales in the future. The development of the modern international market environment is characterized by a high level of competition based on the use of effective management of resources, including both intellectual and financial [2]. The study of the essential content of the elements, foundations and goals of "business excellence", in our opinion, is an important task of modern economics, given the scientific advances on this issue [3], [16]. Socio-economic and geopolitical transformations significantly affect the business processes of market participants.

In particular, the diversification of companies in the industry market, the growing level of increased competition, rapid changes in the needs and requirements of demanding consumers encourages senior management to optimize their economic skills. That is, for a business to succeed, regardless of its scope, size, structure, it has to build a model of management system inherent in the context of business excellence. 


\section{The Purpose of the Article}

There are several models of business improvement around the world, although they are essentially similar, differing only in a set of qualitative characteristics.

Scenario 1.

Envisages further gradual acceleration of the economic growth and formation of appropriate basis for sustainable economic development in the medium term. This scenario predicts: in 2022

real GDP growth by $3.7 \%$ in $2020,3.8 \%$ in 2021 and $4.1 \%$

Consumer Price Index (December to December of preceding year) $-105.5 \%$ in $2020,105.3 \%$ in $2021,105.1 \%$ in 2022.

The average annual exchange rate assumption is UAH 27.0 per USD in 2020, UAH 27.2 per USD in 2021, and UAH 27.5 per USD in 2022/

This forward-looking scenario will be used in the revision of the draft Law of Ukraine On State Budget of Ukraine for 2020 between first and second readings.

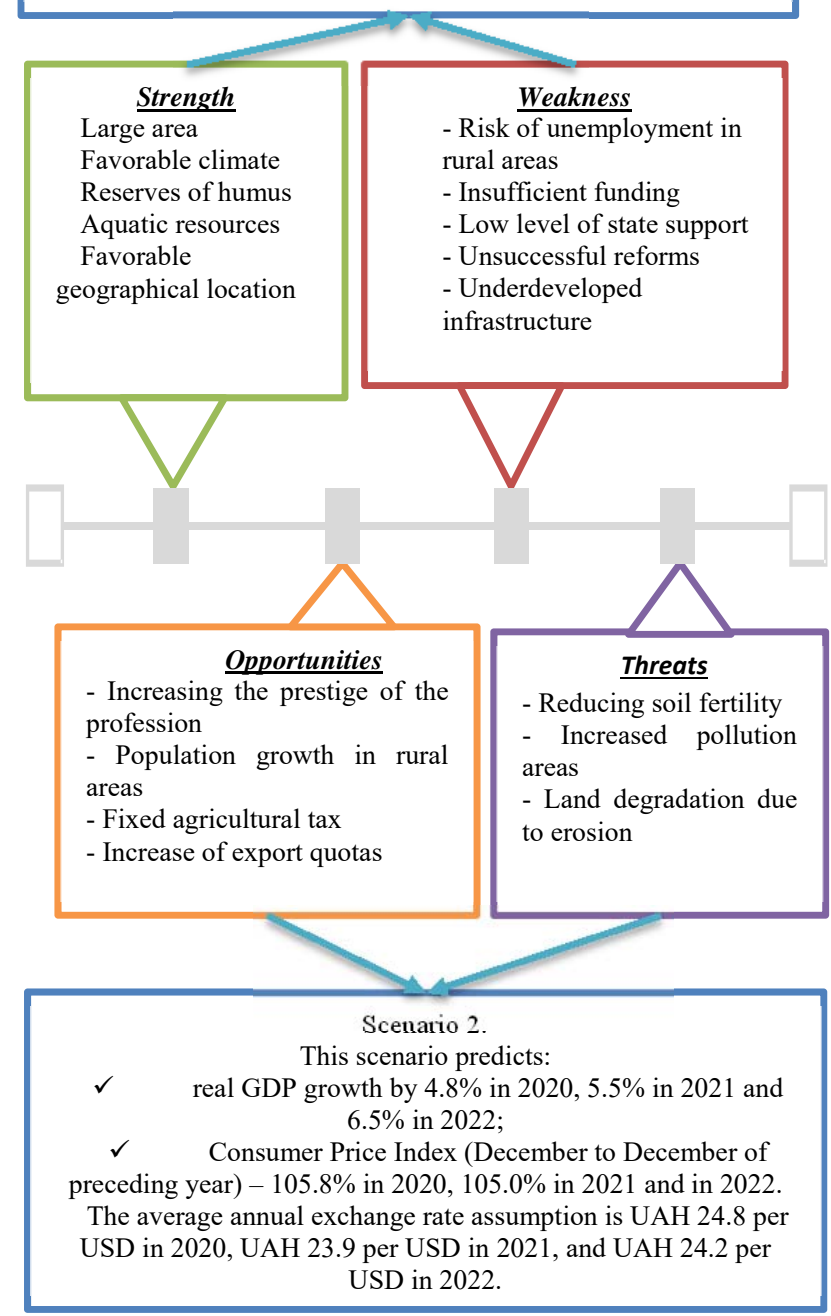

Figure 1. Agribusiness development scenarios of Ukraine ( Source: author's vision )

The economic efficiency of domestic agribusiness in today's conditions has a pronounced regional differentiation, which depends on the influence of resource, investment and other factors [4].

Detailed analysis and assessment of the system of factors are important reserves for improving the competitiveness of domestic agribusiness.
Analyzing the forecast scenario approaches of the Ministry of Economic Development, Trade and Agriculture of Ukraine for 2020-2022, which were approved by the Decree of the Cabinet of Ministers of Ukraine No. 883 of October 23, 2019 "On Amendments to the Decree of the Cabinet of Ministers of Ukraine No. 555 of May 15, 2019" [5].

In view of scientific developments, it should be noted that along with the existing variety of management and marketing tools, the EFQM business excellence model allows determining the methods and basic characteristics of the enterprise, which in turn will objectively assess efficiency [6] of any business unit, which is shown in Figure 2.

Most of the proposed amendments were made taking into account the current economic situation in Ukraine. The reforms envisaged by the Government's action program were also taken into account, in particular: introduction of market circulation of agricultural lands, privatization, reform of labor market rules, demonopolization and strengthening of competition, further deregulation of the economy, implementation of measures to promote Ukrainian exports to foreign markets. Export of Ukrainian goods and services in general, compliance with the postulates of business excellence will increase the level of competitiveness of our state and agribusiness, in particular.

The vector of strategic opportunities identifies strengths and weaknesses. Note that business experience models are frameworks that, when applied in an organization, can help focus thought and action more systematically and in a structured way, which should lead to increased productivity.

The models are holistic in that they focus on all areas and dimensions of the organization, in particular, on the factors that contribute to efficiency. The dynamism of the external environment forms new goals for agricultural enterprises that meet modern market requirements, the main of which is the use of dynamic opportunities. To combat the negative factors of a turbulent environment, it is necessary to develop the flexibility and innovation of enterprises, which is possible through the achievement of business excellence.

The complexity of the system and its structural component for each company is determined individually, based on its needs, the specifics of production of goods, services and industry characteristics. It is worth noting that the appropriate model can be used in combination with any set of tools, depending on the needs of the organization, acting as a single structure to achieve the goal, in the context of a sound strategy. Given the hidden relationship between all subjects of market relations, a key aspect of using the appropriate model is the systematization of the business entity, all elements of 
economic activity, especially those that need priority improvement and refinement. Thus, to motivate and encourage the systematic improvement of economic activity, there are many effective ways to train and retrain employees [7], [16] setting basic goals, which allows the organization to demonstrate success to employees, suppliers and consumers.

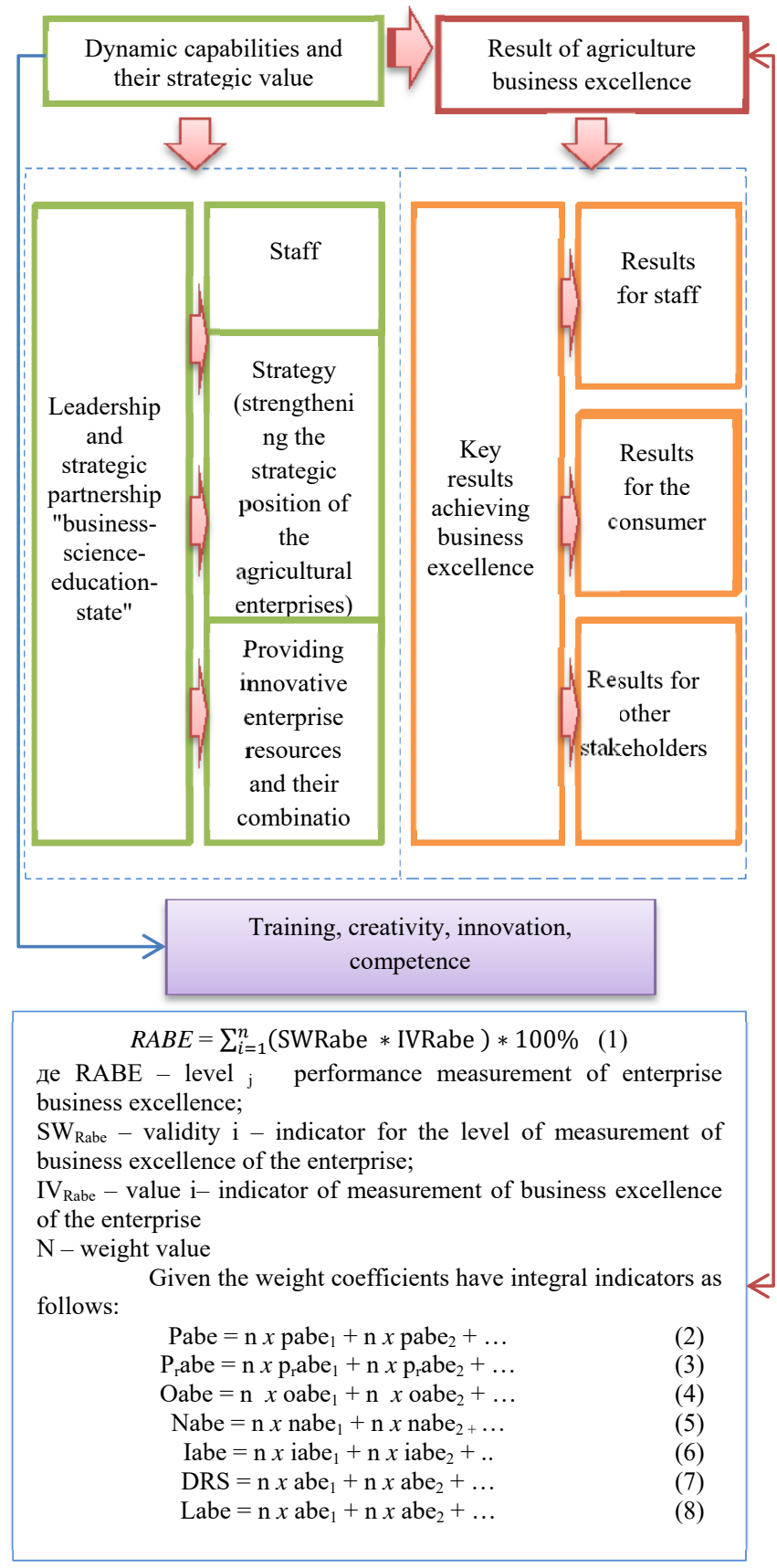

Figure 2. Integrative viewpoint for the implementing sustainable management agricultural business excellence ( Source: Formed by authors )
It is worth noting that companies decide for themselves what level of recognition of business experience they claim depending on many factors, in particular, maturity in the industry and potential.

\section{Results and Discussion}

The realities of today allow us to say that the life of a modern agricultural enterprise can be considered as a constant process of improving its economic activity, which is shown in Figure 3. Therefore, the main postulate of success is to build an effective management system of the business entity in terms of values, competencies and intellectual components of its operation [8]; [9]. However, it should be noted that the strategic vector of development of each business unit is to increase the level of efficiency of its activities, which emphasizes the relevance of research methods and procedures to ensure the success of business excellence management. Given the vector of digitalization, we consider it appropriate to include in the quality management system the goals of the innovation plan, to modernize the entire management system of agricultural machinery. Taking into account the prospects not only of the industry, but also of the enterprises themselves, in the future we consider it expedient to create a table for assessing the innovative skills of agricultural enterprises of Ukraine in accordance with these criteria [16].

The authors of the draft Law on Amendments to the Law of Ukraine "On Stimulating the Development of Domestic Engineering for the AgroIndustrial Complex" note that to improve the situation in this sector of the economy, primarily by providing farms with mobile energy, which in turn will significantly increase the technical equipment of farms and will reduce the average load, which today is more than 105 hectares, while in Canada - 64 hectares, in the US - less than 38, in France - less than 16 , and in the UK - less than 12 hectares. It should be noted that for the revival of domestic agricultural engineering in the country's budget for 2018, investments in the amount of UAH 550 million were provided, and in 2019 this amount doubled; the corresponding trend was forecast for 2020 [10], [16]. 


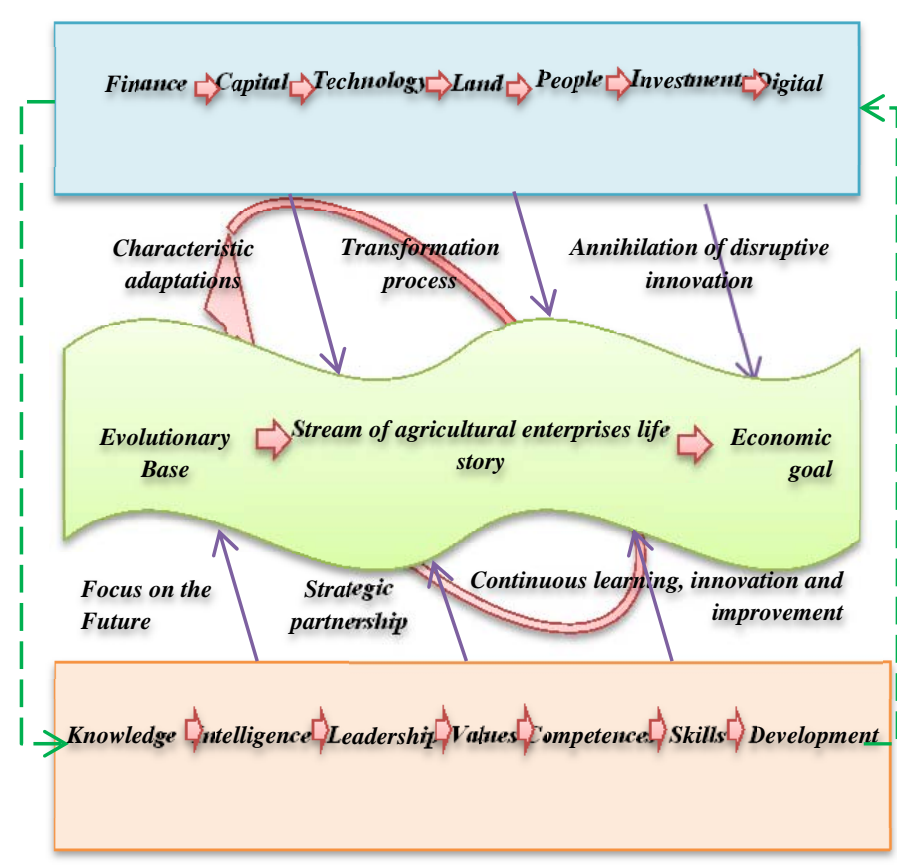

Figure 3. The process of sustainable development of agricultural enterprises

( Source: Formed by authors )

Analyzing the data of Table 1 on innovative business excellence of agricultural machine-building enterprises of Ukraine [11], we can see that for the most part they have almost tangible development trends, but the biggest gap is on the criterion: development strategy based on identifying opportunities, shown in Figure 4.

Table 1. Assessment of innovative excellence of agricultural machine-building companies of Ukraine

\begin{tabular}{|c|c|c|c|c|}
\hline Criteria & \multicolumn{4}{|c|}{ Enterprises } \\
\hline Enablers: & 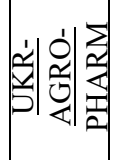 & 新 & 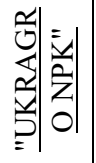 & 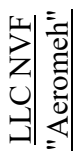 \\
\hline \multicolumn{5}{|c|}{ 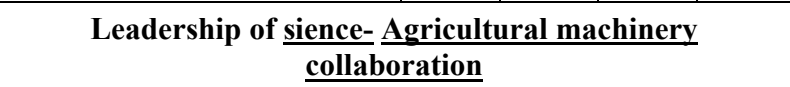 } \\
\hline $\begin{array}{l}\text { Leadership of cooperation } \\
\text { between science and } \\
\text { agricultural industry }\end{array}$ & + & - & + & - \\
\hline $\begin{array}{l}\text { Leadership in achieving } \\
\text { goals and developing the } \\
\text { mission and vision of the } \\
\text { sub-island }\end{array}$ & + & + & + & + \\
\hline $\begin{array}{l}\text { Leadership in business } \\
\text { ethics }\end{array}$ & + & + & + & - \\
\hline \multicolumn{5}{|c|}{ Strategy of sience- Agricultural machinery collaboration } \\
\hline $\begin{array}{l}\text { Strategy of science } \\
\text { cooperation in industry }\end{array}$ & - & - & + & - \\
\hline $\begin{array}{l}\text { Strategic development } \\
\text { based on the use of } \\
\text { innovative technology }\end{array}$ & + & + & - & - \\
\hline $\begin{array}{l}\text { Development strategy based } \\
\text { on the identification of } \\
\text { opportunities }\end{array}$ & - & - & + & + \\
\hline
\end{tabular}

\begin{tabular}{|c|c|c|c|c|}
\hline \multicolumn{5}{|c|}{ People of sience- $\underline{\text { Agricultural machinery collaboration }}$} \\
\hline $\begin{array}{l}\text { Identification of innovative } \\
\text { staff competencies }\end{array}$ & + & - & - & + \\
\hline $\begin{array}{l}\text { Digitalization of the } \\
\text { personnel management } \\
\text { process }\end{array}$ & + & + & - & - \\
\hline \multicolumn{5}{|c|}{$\begin{array}{c}\text { Partnerships and resources of sience- Agricultural } \\
\text { machinery collaboration }\end{array}$} \\
\hline $\begin{array}{l}\text { Level of cooperation } \\
\text { between universities and } \\
\text { industry }\end{array}$ & - & - & + & - \\
\hline $\begin{array}{l}\text { Introduction of gadgets and } \\
\text { other technologies }\end{array}$ & + & - & - & - \\
\hline $\begin{array}{l}\text { Efficiency of providing } \\
\text { resources to enterprises }\end{array}$ & + & + & + & - \\
\hline \multicolumn{5}{|c|}{$\begin{array}{c}\text { Processes, products and services of } \underline{\text { sience- }} \text { Agricultural } \\
\text { machinery collaboration }\end{array}$} \\
\hline $\begin{array}{l}\text { Інноваційне управління } \\
\text { процесами виробництва }\end{array}$ & + & + & - & - \\
\hline \multicolumn{5}{|c|}{$\underline{\text { Results of sience- Agricultural machinery collaboration }}$} \\
\hline People results & + & + & + & - \\
\hline $\begin{array}{l}\text { Providing highly qualified } \\
\text { personnel }\end{array}$ & + & - & -- & + \\
\hline \multicolumn{5}{|c|}{$\begin{array}{c}\text { Customer results of sience- Agricultural machinery } \\
\text { collaboration }\end{array}$} \\
\hline $\begin{array}{l}\text { Satisfying the needs of the } \\
\text { discerning consumer }\end{array}$ & - & + & + & - \\
\hline \multicolumn{5}{|c|}{ Society results of $\underline{\text { sience- }} \underline{\text { Agricultural machinery }}$} \\
\hline $\begin{array}{l}\text { Innovative development of } \\
\text { domestic agricultural } \\
\text { industry }\end{array}$ & - & - & + & - \\
\hline
\end{tabular}

Source: authors' development

In our opinion, an integral part of scientific and technical policy in the field of agricultural machinery should be strengthening information activities, promoting technological, technical, environmental and economic efficiency of domestic agricultural machinery by demonstrating technological complexes of machinery and equipment directly at agricultural enterprises, exhibitions. Undoubtedly, in the course of studying the factors influencing the innovative development of agricultural engineering, the very specifics of this industry were studied [12].

Accordingly, knowing the specifics and factors of influence, one can choose a set of measures to intensify the process of formation and implementation of innovations for the development of the national agro-industrial complex. To objectively identify the key factors influencing the development of innovative processes in agricultural engineering, the study formed a list of indicators that, in our opinion, will not only qualitatively assess the state of the industry, but also quantitatively, which will describe in detail the prospects for development and outline. In view of the above, it is appropriate to note the prospects for the development of Ukraine's agricultural sector, as the lion's share of criteria, of course, encourages the increase of innovative key business principles [13], [14], [15], [16]. 


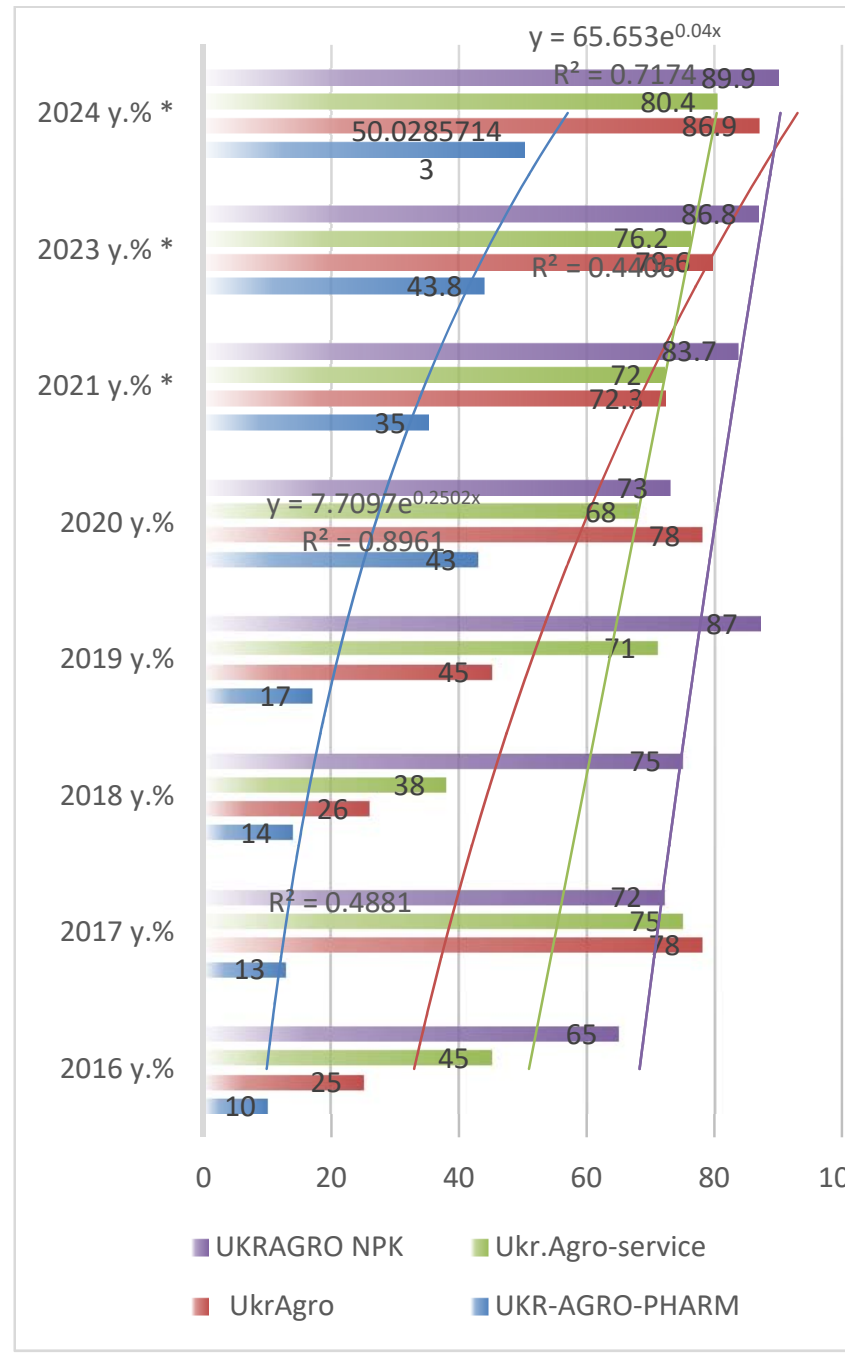

Figure 4. Forecasting the level of ensuring business excellence of agricultural enterprises in Ukraine ( Source: Formed by author)

The introduction of innovative technologies in agricultural enterprises can be carried out primarily through the interaction of external and internal environment, taking into account the resource potential, integration and configuration, which will ensure the successful implementation of this mechanism taking into account Ukraine's European integration. Undoubtedly, the introduction of innovations for agricultural enterprises opens new horizons of development, through the renewal of material and technological base, the use of advanced technologies in animal husbandry and crop production, the use of biotechnology, which allows obtaining new, useful and higher quality products.

In the course of our research we have developed proposals and a number of measures to increase the level of business excellence of agricultural enterprises, shown in Figure 7. Therefore, all proposals and recommendations have to be developed taking into account the specifics of the agricultural sector [16].
Proposal to increase the level of rural business activity after COVID-19

Implementation of the
developed
recommendations:
1. Management level
Formation of the
organizational and
economic mechanism of
introduction of key bases of
business competence of the
enterprise.

\section{Management decisions}

- Evaluation of recommendations;

- Assessing the possibilities of implementing measures taking into account the specifics of the activity;

- Planning of future financial results of activity;

- Adjustment of the developed offers according to dynamic market opportunities;

enterprise.

2. Production level

Implementation of clearly defined tasks, introdiction

of innovative technologies in agricultural prodiction

to minimize costs and

maximize value.

3. Level of funding

Forecasting cash flows and investments needed to improve the material and technical base of the enterprise.

4. Performance forecasting Modeling the further development of an agricultural enterprise in accordance with the goals, opportunities, abilities and competencies.

Optimization

Consumer goals: establishing an effective sales system; formation of a reliable customer base.

Organizational resources: strengthening the brand reputation; promotion of activities; increasing the effectiveness of advertising activities in the B2B market, the use of innovative methods of promoting goods on the market and the formation of a positive image.

Human resources for the formation of innovative staff competencies, human resources, training, development programs and training; flexible system of adaptation and response to market, market, economic changes and trends, etc.

Technological resources: the use of innovative technologies in agricultural production, increasing the level of digitalization of activities.

Management resources: formation of an effective management staff; clear implementation of the formed managerial decisions, strategic intentions, increase of efficiency of marketing researches; strengthening corporate, business and personal ties, establishing and maintaining contacts of the strategic partnership "business education-state" Material resources: updating and optimization of fixed assets; establishment of resource supply channels; formation of effective combinations of resource substitutes. Financial resources: increasing economic and investment attractiveness; ensuring financial stability.

Figure 5. Proposal to increase the level of rural business activity after COVID-19

( Source: Formed by author)

Given the experience, we can identify integral components of the process of developing measures that are inherent in the studied enterprises: assessment of feasibility, economic feasibility, adjustment according to the specifics of activities and strategic intentions and development of ways to improve. The result is the outline of prospects for further development and economic justification of the developed proposals. The contribution of the 
study to the development of domestic agricultural engineering is possible through the introduction of such measures, namely [16]:

$\checkmark$ identification of innovative technical and technological solutions, analysis of the market of foreign and domestic equipment, study of development trends and the establishment of a priority list of machinery and equipment, as well as the establishment of requirements for the latest technologies;

$\checkmark$ innovative support of agricultural machinery through the development and implementation of specific business plans for the development of competitive machinery, justification of terms of reference, technical conditions, design of new equipment using modern computer technology, use of the claimed element base, prototyping, certification and development;

$\checkmark$ Formation of investment attractiveness of machine-building enterprises and conditions of sustainable innovative production of machines due to modernization of production facilities, customs-tariff and tax regulation, export-import, depreciation and preferential financial and credit policy with variable taxation by years and volumes. Domestic manufacturers of modern priority equipment. by declaring producers their intentions of production with determination of degrees and dynamics of localization;

$\checkmark$ Regulation of the agricultural machinery market by stimulating the renewal of the technical park by improving financial leasing, reducing medium-term and long-term loans, improving the commissioning of machinery, protecting the domestic market of agricultural machinery and equipment and introducing state register, maintenance systems;

$\checkmark \quad$ Legislative and regulatory support on the basis of changes to current legislation, customs and tax codes, technical regulation in the system of engineering and technical support, harmonization of regulations in accordance with the requirements of the European Union;

$\checkmark$ Optimization of the general management system and coordination of interests of the state, farmers and machine-building enterprises in the conditions of increase of level of investment attractiveness that, in turn, will increase competitiveness of domestic production at the expense of import substitution.

Agricultural activities aimed at improving economic, social, organizational, technological and environmental efficiency. Special mention should be made of the use of innovative technologies, environmental innovations, which, accordingly, increase productivity, productivity, minimize losses and ensure environmental safety. Assessment of innovative development of agricultural farms in Ukraine shows that among the implemented technological innovations the largest share is accounted for by agricultural technologies, most of which are related to the introduction of new methods and ways of applying fertilizers and plant protection.
Therefore, among the significant shortcomings of innovation in agriculture is the lack of innovative projects which include the creation of breeding and genetic innovation aimed primarily at increasing the productivity of crops and animals, the introduction of new resource-saving technologies, innovation, and consulting systems in science, technology and innovation.

\section{Conclusions}

The results of the study revealed the following:

$\checkmark$ In our opinion, the modern method for assessing the level of efficiency of the enterprise is the method of business excellence. In the course of the research, it was established that the key postulates of "business excellence of business" are based on innovative aspects of the development of the modern business environment. For further research, we have identified the most successful key factors of global models of business excellence.

$\checkmark$ We emphasize the expediency of continuing our research, because it is the model of business experience, which is the main tool for evaluating the company's activities, is relevant for European and Ukrainian companies. Ideal companies use the criteria of the business experience model to improve certain aspects of their activities, including: defining goals and strategies, establishing partnerships with consumers and suppliers, motivating and attracting staff, production and sale of competitive products.

$\checkmark \quad$ It should be noted that a number of benefits we receive from the use of the proposed algorithm for integrated assessment of the level of business excellence is a clear identification of the structure of core values; holistic general idea of the management of the enterprise; a valuable tool for analyzing and evaluating the development of the business entity; a clear outline of the vision for continuous improvement based primarily on the optimization of key performance indicators. Formation of the enterprise management system on the basis of a balanced system of key performance indicators; formation of innovative staff competencies.

$\checkmark$ To date, given the dynamics of factors influencing the activities of the enterprise, it is difficult to outline a complete picture of the activities of the enterprise to use only quantitative methods. That is why, in our scientific publication, we have proposed our own algorithm for assessing the level of business excellence. However, our estimation algorithm allows the use of exponential equations, which is due to any changes in indicators. Agricultural enterprises were used as a base of practice, 
because in our opinion, this sector of Ukraine's economy is the most promising for prosperity.

$\checkmark$ As the innovative development of the agricultural sector is renewed today, and given the significant competition, a necessary condition for success is the use of new approaches and mechanisms to achieve business excellence. Therefore, in the course of the research we formed a factor-result matrix with the indication of key identifiers for the assessment of innovative skills in the business of the agricultural sector of Ukraine. We believe that compliance with the relevant identifiers will contribute to the innovative development of domestic agribusiness, which, in turn, will increase the efficiency of both the sector and the economy as a whole.

$\checkmark \quad$ To date, there is no single established model of business excellence, which is why our proposed algorithm for evaluating and developing proposals to improve the level of business excellence of agricultural enterprises, are relevant and require further research. Based on the above, we believe that an important priority for the development of agricultural enterprises in Ukraine is the availability of dynamic opportunities in the formation of sustainable competitive advantages through the implementation of innovative technologies and ensuring the improvement of business excellence.

\section{References}

[1]. Tanklevska, N., Riepina, I. M., Tkachenko, O., \& Kuklin, O. (2020). Dynamic modeling of agricultural company asset management process. The National Academy of Sciences of the Republic of Kazakhstan. Doi: 10.32014/2020.2518-1467.112

[2]. Riepina, I., Chukhraieva, N., \& Kehrein, E. (2020). The Influence Of Market Risks Upon The Agribusiness Value. Management Theory and Studies for Rural Business and Infrastructure Development, 42(1), 35-40.

Doi: 10.15544/MTS.2020.04

[3]. Andriushchenko, K., Sahaidak, M., Tepliuk, M., Ishchenko, M., \& Domina, O. (2019). Prerequisites for the creation of financial and credit infrastructure of support for agricultural enterprises in Ukraine. Banks and Bank Systems, 14(2), 63-75.

Doi: 10.21511/bbs.14(2).2019.06

[4]. Polishchuk, Y., Ivashchenko, A., Britchenko, I., Machashchik, P., \& Shkarlet, S. (2019). European smart specialization for Ukrainian regional development: Path from creation to implementation. Problems and Perspectives in Management, 17(2), 376-391.

Doi: $10.21511 / \mathrm{ppm} .17(2) .2019 .29$
[5]. Gontareva, I. V. (2011). Influence of timeliness in reproduction processes upon system efficiency of enterprise development. Actual Problems of Economics, (116), 69-76.

[6]. Boichenko, K. S., Tepliuk, M. A., Rekova, N. Y., Stashkevych, I. I., \& Morkunas, M. (2019). Management of fluctuation of financial and economic integrated development of innovative enterprise. Financial and credit activity: problems of theory and practice, 3(30), 62-69.

Doi: 10.18371/fcaptp.v3i30.179506

[7]. Sahaidak, M., Tepliuk, M., Dykan, V., Popova, N., \& Bortnik, A. (2020). cOmprehenSiVe ASSeSSment Of influence $O f$ the innOVAtiVe DeVelOpment ASYmmetrY On functiOning Of the inDuStriAl enterpriSe. Natsional'nyi Hirnychyi Universytet. Naukovyi Visnyk, (6), 162-167.

Doi: $10.33271 /$ nvngu/2020-6/162

[8]. Tepliuk, M. A., Liezina, A. V., Zavyalova, M. V., Lysenko, N. S., \& Yavorska, A. F. (2020), Valuable aspects in the enterprise management process. Financial and Credit Activity-Problems of Theory and Practice, 1(32), 206-212.

Doi: 10.18371/FCAPTP.V1I32.200371.

[9]. Jacobs, B. W., Singhal, V. R., \& Subramanian, R. (2010). An empirical investigation of environmental performance and the market value of the firm. Journal of Operations Management, 28(5), 430-441.

Doi: 10.1016/j.jom.2010.01.001.

[10]. Kassinis, G., \& Vafeas, N. (2006). Stakeholder pressures and environmental performance. Academy of Management Journal, 49(1), 145-159.

Doi: 10.5465/amj. 2006.20785799.

[11]. Keeble, J. J., Topiol, S., \& Berkeley, S. (2003). Using indicators to measure sustainability performance at a corporate and project level. Journal of Business Ethics, 44(2), 149-158.

Doi: 10.1023/a:1023343614973.

[12]. Kirieieva, E. A., Pryshliak, N. V., Shamanska, O. I., Salkova, I. Y., \& Kucher, A. V. (2019). Strategic priorities and financial support of Ukrainian agricultural sector development. International Journal of Ecological Economics \& Statistics.-2019.-Vol. 40, Num. 2.-P. 25-37.

[13]. Boichenko, K., Mata, M. N., Mata, P. N., \& Martins, J. N. (2021). Impact of financial support on textile enterprises' development. Journal of Risk and Financial Management, 14(3), 135. Doi: $10.3390 / \mathrm{jrfm} 14030135$

[14]. Dyba, M., Gernego, I., Dyba, O., \& Oliynyk, A. (2020). Financial Support And Development Of Digital Rural Hubs In Europe. Management Theory and Studies for Rural Business and Infrastructure Development, 42(1), 51-59.

[15]. Mayorova, T., Domżał, Z., Gernego, I., \& Dyba, O. (2019). High-Technology Investments As A Driver Of Rural Productivity. Management Theory and Studies for Rural Business and Infrastructure Development, 41(1), 25-32.

Doi: $10.15823 / \mathrm{mts} .2019 .03$

[16] Sahaidak, M., Tepliuk, M., Zhurylo, V., Rudenko, N., \& Samko, O. (2021). Integrative Viewpoint for Implementing Sustainable Management Agricultural Business Excellence. TEM Journal, 10(1), 303-309. 